\title{
Interactive effect of genetic polymorphism of glutathione S-transferase M1 and smoking on squamous cell lung cancer risk in Korea
}

\author{
KYOUNG-MU LEE ${ }^{1}$, DAEHEE KANG ${ }^{1}$, SEUNG-JOON LEE ${ }^{4}$, SUE KYUNG PARK ${ }^{5}$, \\ KWAN-HEE LEE ${ }^{6}$, JI-YEOB CHOI ${ }^{1}$, SOO-UNG KIM ${ }^{2}$, HWANG CHOI ${ }^{2}$, \\ SEUNG-HO CHOI ${ }^{3}$, YOUNG-WHAN KIM ${ }^{3}$, YUN-CHUL HONG ${ }^{1}$ and SOO-HUN CHO ${ }^{1}$
}

\begin{abstract}
${ }^{1}$ Department of Preventive Medicine and Institute of Environmental Medicine, ${ }^{2}$ Urology and ${ }^{3}$ Internal Medicine, Seoul National University College of Medicine, Cancer Research Institute, 28 Yongon-Dong, Chongno-Gu, Seoul 110-799;

${ }^{4}$ Department of Internal Medicine, Hallym University College of Medicine, 1 Okchon-Dong, Chunchon, Kangwon-Do;

${ }^{5}$ Department of Preventive Medicine, Konkuk University College of Medicine, 322 Danwal-Dong, Chungju,

Chungcheongbuk-Do 380-701; ${ }^{6}$ Department of Occupational Medicine, Inha University College of Medicine, 253 Younhyn-Dong, Nam-Gu, Inchon, Korea
\end{abstract}

Received August 8, 2005; Accepted October 17, 2005

\begin{abstract}
To evaluate the role of the genetic polymorphisms of CYP2E1, GSTM1 and GSTT1, and their interaction with smoking in lung cancer development in Korean males, a hospital-based case-control study was conducted. Histologically confirmed male lung cancer patients $(n=171)$ and male patients with no present or previous history of systemic illness who visited the urology department $(n=196)$ were recruited from Seoul National University Hospital, Korea (1998-1999). CYP2E1 genotypes were determined by PCRRFLP using RsaI digestion and GSTMI and T1 genotypes were determined by multiplex PCR. Risks were estimated as odds ratios (ORs) and 95\% confidence intervals (CIs) using a logistic regression model adjusting for age and pack-year. Smoking was a significant risk factor for lung cancer $(\mathrm{P}<0.001)$. Although genetic polymorphisms of CYP2E1, GSTM1 and $T 1$ were not associated with the overall risk of lung cancer, the GSTM1 null genotype significantly increased the risk of squamous cell lung cancer $(\mathrm{OR}=1.9,95 \% \mathrm{CI}=1.04-3.60)$. An interactive effect between the GSTM1 null genotype and smoking was observed $(\mathrm{P}=0.04)$. These results suggest that the GSTM1 null genotype is associated with squamous cell lung cancer and modifies the effect of smoking on squamous cell lung cancer development in Korean males.
\end{abstract}

Correspondence to: Dr Soo-Hun Cho, Department of Preventive Medicine, Seoul National University College of Medicine, 28 Yongon-Dong, Chongno-Gu, Seoul 110-799, Korea

E-mail: chosuh@snu.ac.kr

Key words: lung cancer, CYP2E1, GSTM1, GSTT1, smoking, interaction

\section{Introduction}

Lung cancer is the most prevalent cancer worldwide. There was an estimated 1.24-million new cases of lung cancer in 2000 (1). Lung cancer mortality is also the highest in the world and in Korea $(1,2)$.

Cigarette smoke, the major risk factor for lung cancer, contains a variety of carcinogens, such as polycyclic aromatic hydrocarbons (PAHs), N-nitrosoamins, and aromatic/heterocyclic amines (3). These carcinogens go through metabolic pathways by a number of enzyme systems, including $\mathrm{P} 450$ (CYP), glutathione S-transferase (GST) and N-acetyltransferase (NAT).

CYP2E1 catalyzes the oxidation of various $\mathrm{N}$-nitrosamines, including potent tobacco-specific procarcinogens such as 4(methylnitrosoamino)-1-(3-pyridyl)-1-butanone (NNK) (4). The association between genetic polymorphisms of CYP2E1 (DraI, Pst I and RsaI) and lung cancer risk showed inconsistent results; the protective effect of CYP2E1 RsaI $c 2$ allele (5-7) or no association with $c 2$ allele $(8,9)$.

GSTM1 catalyzes reactive electrophilic intermediates derived from cigarette smoking, such as BaP 7,8-diol-9,10epoxides (BPDE), to less reactive and more easily excreted glutathione conjugates (10). Although earlier meta-analysis concluded that the GSTM1 null genotype is associated with an increased risk of lung cancer $(11,12)$, recent pooled analyses indicated that there is no evidence of an increased risk of lung cancer in the GSTMI null genotype (13). Moreover, studies conducted in the Asian population also showed inconsistent results (14-17). The results of previous studies on the association between the GSTT1 null genotype and lung cancer risk are also inconsistent (18-20).

The lack of consistency might be due to the difference in ethnicity, genotype distribution, exposure to possible risk factors or risk modifiers, such as smoking, diet, and occupational chemicals, and distribution of histological cell types of lung cancer cases. The distribution of histological 
cell types might be one of the reasons for the inconsistent results because of the heterogeneity of lung cancer risk by histological cell types (6). However, the potential role of genetic polymorphisms of CYP $2 E 1$, GSTM1 and $T 1$ in a specific histological cell type of lung cancer with the interactive effect of smoking has not been thoroughly evaluated.

The purpose of this study was to determine the potential role of genetic polymorphisms of CYP2E1 RsaI, GSTM1, and $T 1$ homozygous deletions in the overall risk of lung cancer and the specific cell types in Korean males. The interactive effect of these polymorphisms and smoking on lung cancer development was also evaluated.

\section{Materials and methods}

Subjects and data collection. Histologically confirmed male lung cancer patients who were 40 years or more in age were recruited as cases $(n=180)$ from the Department of Internal Medicine, Seoul National University Hospital, Korea, from February 1998 to July 1999. Male patients who were also 40 years or more in age and visited the Department of Urology, Seoul National University Hospital were recruited as controls $(n=223)$. Those with a history of malignant tumors or radiotherapy and chemotherapy were excluded from both cases and controls. Controls consisted of urolithiasis, benign prostatic hyperplasia, urethral stricture, hernia, and so on (21). Using these eligibility criteria, 171 lung cancer cases and 196 controls were selected. Information on age and smoking history as pack-years was collected by personal interview and medical record review.

Genotyping. From the subjects, $5 \mathrm{cc}$ of peripheral blood was collected in an EDTA tube with informed consent. DNA was extracted from each blood sample using a Qiagen DNA extraction kit (Chatsworth, CA, USA) and stored at $-20^{\circ} \mathrm{C}$ until genotyping.

CYP2E1 genotypes were determined by polymerase chain reaction-restriction fragment length polymorphism (PCRRFLP) method with RsaI digestion. In the CYP2E1 genotyping analysis, primers (5'-CCA GTC GAG TCT ACA TTG TCA-3' and 5'-TTC ATT CTG TCT TCT AAC TGG-3') were used in the PCR employing the following amplification conditions: the $20 \mu 1$ reaction mixtures contained $1.5 \mathrm{mM}$ $\mathrm{MgCl}_{2}, 250 \mu \mathrm{M}$ dNTPs, $1 \mu \mathrm{M}$ primers, $1 \mu \mathrm{M}$ template DNA and $1 \mathrm{U}$ of Taq polymerase with the buffer (10 mM Tris$\mathrm{HCl}, \mathrm{pH} 9.0 ; 40 \mathrm{mM} \mathrm{KCl}$ ) (Bioneer, Daejeon, Korea). After initial denaturation at $94^{\circ} \mathrm{C}$ for $4 \mathrm{~min}, 34$ cycles of $60 \mathrm{sec}$ at $94^{\circ} \mathrm{C}, 60 \mathrm{sec}$ at $60^{\circ} \mathrm{C}$ and $60 \mathrm{sec}$ at $72^{\circ} \mathrm{C}$ were performed, followed by a final extension step of $4 \mathrm{~min}$ at $72^{\circ} \mathrm{C}$. After $\mathrm{PCR}$, an aliquot of the product was digested with $R s a \mathrm{I}$ for $3 \mathrm{~h}$ at $37^{\circ} \mathrm{C}$.

The GSTM1 and GSTT1 genotypes were determined by multiplex polymerase chain reaction (PCR). The $\beta$-globin specific primer pair (B1, 5'-CAA CTT CCA CGT TCA CC-3'; and B2, 5'-GAA GAC CCA AGG ACA GGT AC-3') was used together with the GSTM1 specific primer pair (G1, 5'GAA CTC CCT GAA AAG CTA AAG C-3'; and G2, 5'GTT GGG CTC AAA TAT ACG GTG G-3') and the GSTT1 specific primer pair (T1, 5'-TTC CTT ACT GGT CCT CAC ATC TC-3'; and T2, 5'-TCA CCG GAT CAT GGC CAG
Table I. Age distribution, smoking history and pathological type of 171 lung cancer cases and 196 hospital controls.

\begin{tabular}{|c|c|c|c|}
\hline & $\begin{array}{c}\text { No. of } \\
\text { cases }(\%)\end{array}$ & $\begin{array}{c}\text { No. of } \\
\text { controls }(\%)\end{array}$ & P-value \\
\hline \multicolumn{4}{|l|}{ Age } \\
\hline 40-59 & $73(42.7)$ & $82(41.8)$ & 0.87 \\
\hline$\geq 60$ & $98(57.3)$ & $114(58.2)$ & \\
\hline Mean \pm SD & $61.0 \pm 8.4$ & $62.1 \pm 12.2$ & 0.34 \\
\hline \multicolumn{4}{|l|}{ Smoking history ${ }^{\mathrm{a}}$} \\
\hline $\begin{array}{l}\text { (<400 cigarettes/lifetime) } \\
\text { Ever }\end{array}$ & $14(8.3)$ & $35(18.6)$ & $<0.001$ \\
\hline ( $\geq 400$ cigarettes/lifetime) & $154(91.7)$ & $153(81.4)$ & \\
\hline \multicolumn{4}{|l|}{ Pack-year in ever smokers } \\
\hline $0<\mathrm{PY}<35$ & $52(33.8)$ & $108(70.6)$ & 0.001 \\
\hline $\mathrm{PY} \geq 35$ & $102(66.2)$ & $45(29.4)$ & \\
\hline Mean \pm SD & $40.6 \pm 16.1$ & $26.0 \pm 19.4$ & $<0.001$ \\
\hline \multicolumn{4}{|l|}{ Pathological type } \\
\hline Adenocarcinoma & $48(28.1)$ & & \\
\hline Squamous cell carcinoma & $74(43.3)$ & & \\
\hline Small cell carcinoma & $31(18.1)$ & & \\
\hline Other cell types & $18(10.5)$ & & \\
\hline
\end{tabular}

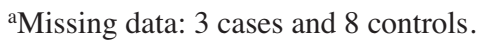

CA-3') in PCR reactions. PCR was carried out in a total volume of $50 \mu 1$, containing $5 \mu \mathrm{l}$ of DNA template (50-100 $\mathrm{ng}$ ), 50 pmole of each of the above primers, and 1.25 units of Taq polymerase (Promega, Madison, WI, USA). The reaction was incubated at $94^{\circ} \mathrm{C}$ for $4 \mathrm{~min}$, prior to 30 cycles of denaturation for $20 \mathrm{sec}$ at $94^{\circ} \mathrm{C}$, annealing for $20 \mathrm{sec}$ at $57^{\circ} \mathrm{C}$, and extension for $45 \mathrm{sec}$ at $72^{\circ} \mathrm{C}$, followed by a final extension of $5 \mathrm{~min}$ at $72^{\circ} \mathrm{C}$. Subsequent to PCR, an $10 \mu \mathrm{l}$ aliquot was run on a $3 \%$ Metaphor agarose gel (FMC BioProducts, Rockland, ME, USA) in ethidium bromidestained TAE buffer (50 Volt, $1 \mathrm{~h}$ ), after which the bands were visualized and photographed under UV transillumination. The internal standard fragment amplified from B-globin was $268 \mathrm{bp}$ in length, whereas the presence of GSTM1 and GSTT1 genes was identified by 210-bp and 480-bp fragments, respectively.

The reliability of the PCR analyses conducted in the Korean laboratory was controlled by re-assaying 40 randomly selected samples in the Finnish laboratory; the results were found to be identical in both laboratories.

Statistical analyses. The risk of lung cancer was estimated as odds ratio (OR) and $95 \%$ confidence interval (CI) by unconditional logistic regression adjusting for age and packyear. Age and pack-year were used as continuous variables in the model. Considering statistical power, CYP2E1 genotypes were divided into two categories $(\mathrm{c} 1 / \mathrm{c} 2+\mathrm{c} 2 / \mathrm{c} 2$ vs. $\mathrm{c} 1 / \mathrm{c} 1)$ as GSTM1 and T1 genotypes (present vs. null). Stratified analyses for cases with specific histological cell types (adenocarcinoma, 
Table II. CYP2E1, GSTM1, GSTT1 genotypes and lung cancer risk by histological type in Korean males.

\begin{tabular}{|c|c|c|c|c|c|c|c|c|c|}
\hline & $\begin{array}{c}\text { No. of } \\
\text { controls } \\
(\%)\end{array}$ & $\begin{array}{l}\text { No. of } \\
\text { all cases } \\
(\%)\end{array}$ & $\begin{array}{c}\text { OR } \\
(95 \% \mathrm{CI})\end{array}$ & $\begin{array}{c}\text { No. of } \\
\text { adeno- } \\
\text { carcinoma } \\
(\%)\end{array}$ & $\begin{array}{c}\text { OR } \\
(95 \% \mathrm{CI})\end{array}$ & $\begin{array}{c}\text { No. of } \\
\text { squamous cell } \\
\text { carcinoma } \\
(\%)\end{array}$ & $\begin{array}{c}\text { OR } \\
(95 \% \mathrm{CI})\end{array}$ & $\begin{array}{c}\text { No. of } \\
\text { small cell } \\
\text { carcinoma } \\
(\%)\end{array}$ & $\begin{array}{c}\text { OR } \\
(95 \% \mathrm{CI})\end{array}$ \\
\hline $\begin{array}{c}C Y P 2 E 1 \\
\mathrm{c} 1 / \mathrm{c} 1\end{array}$ & $90(47.1)$ & 64 (37.9) & $\begin{array}{c}1.0 \\
\text { (reference) }\end{array}$ & $17(36.2)$ & $\begin{array}{c}1.0 \\
\text { (reference) }\end{array}$ & $30(41.1)$ & $\begin{array}{c}1.0 \\
\text { (reference) }\end{array}$ & $11(35.5)$ & $\begin{array}{c}1.0 \\
\text { (reference) }\end{array}$ \\
\hline $\mathrm{c} 1 / \mathrm{c} 2$ & 89 (46.6) & $97(57.4)$ & $\begin{array}{c}1.3 \\
(0.81-2.11)\end{array}$ & $28(59.6)$ & $\begin{array}{c}1.6 \\
(0.77-3.15)\end{array}$ & $37(50.7)$ & $\begin{array}{c}1.1 \\
(0.57-1.97)\end{array}$ & $20(64.5)$ & $\begin{array}{c}1.9 \\
(0.80-4.58)\end{array}$ \\
\hline $\mathrm{c} 2 / \mathrm{c} 2$ & $12(6.3)$ & $8(4.7)$ & $\begin{array}{c}0.8 \\
(0.29-2.22)\end{array}$ & $2(4.3)$ & $\begin{array}{c}0.8 \\
(0.16-3.97)\end{array}$ & $6(8.2)$ & $\begin{array}{c}1.4 \\
(0.45-4.16)\end{array}$ & - & - \\
\hline $\mathrm{c} 1 / \mathrm{c} 2+\mathrm{c} 2 / \mathrm{c} 2$ & $101(52.9)$ & $105(62.1)$ & $\begin{array}{c}1.2 \\
(0.78-1.98)\end{array}$ & $30(63.9)$ & $\begin{array}{c}1.5 \\
(0.73-2.90)\end{array}$ & 43 (58.9) & $\begin{array}{c}1.1 \\
(0.60-1.99)\end{array}$ & $20(64.5)$ & $\begin{array}{c}1.7 \\
(0.70-3.96)\end{array}$ \\
\hline $\begin{array}{l}\text { GSTM1 } \\
\text { Present }\end{array}$ & $91(46.4)$ & $71(42.0)$ & $\begin{array}{c}1.0 \\
\text { (reference) }\end{array}$ & $22(45.8)$ & $\begin{array}{c}1.0 \\
\text { (reference) }\end{array}$ & $24(32.9)$ & $\begin{array}{c}1.0 \\
\text { (reference) }\end{array}$ & $19(63.3)$ & $\begin{array}{c}1.0 \\
\text { (reference) }\end{array}$ \\
\hline Null & $105(52.6)$ & $98(58.0)$ & $\begin{array}{c}1.4 \\
(0.85-2.14)\end{array}$ & $26(54.2)$ & $\begin{array}{c}1.1 \\
(0.57-2.13)\end{array}$ & $49(67.1)$ & $\begin{array}{c}1.9 \\
(1.04-3.60)\end{array}$ & $11(36.7)$ & $\begin{array}{c}0.6 \\
(0.24-1.33)\end{array}$ \\
\hline $\begin{array}{l}\text { GSTT1 } \\
\text { Present }\end{array}$ & $89(45.4)$ & $89(52.7)$ & $\begin{array}{c}1.0 \\
\text { (reference) }\end{array}$ & $26(54.2)$ & $\begin{array}{c}1.0 \\
\text { (reference) }\end{array}$ & $39(53.4)$ & $\begin{array}{c}1.0 \\
\text { (reference) }\end{array}$ & $12(40.0)$ & $\begin{array}{c}1.0 \\
\text { (reference) }\end{array}$ \\
\hline Null & 107 (54.6) & $80(47.3)$ & $\begin{array}{c}0.7 \\
(0.45-1.12)\end{array}$ & $22(45.8)$ & $\begin{array}{c}0.6 \\
(0.33-1.24)\end{array}$ & 34 (46.6) & $\begin{array}{c}0.7 \\
(0.39-1.27)\end{array}$ & $18(60.0)$ & $\begin{array}{c}1.1 \\
(0.46-2.46)\end{array}$ \\
\hline
\end{tabular}

ORs were adjusted for age and pack-year.

squamous cell carcinoma, and small cell carcinoma) were also performed.

Gene-smoking interactions, i.e. the modification of an increasing pattern of lung cancer risk as the pack-year increases by different genotype, were evaluated by the significance of the coefficient of product term genotype*pack-year in the model without main effect term of genotype as follows; Logit (lung cancer) $=\beta_{0}+\beta_{1}$ age $+\beta_{2}$ pack-year $+\beta_{3}$ genotype* packyear (22). This model assumes that, if there is no exposure to cigarette smoking, there is no difference in the risk of lung cancer between genotypes (23). The test was equal to evaluate the difference of the slopes of two fitted lines stratified by categorized genotypes with common intercept assumption. The assumption was tested by evaluating the significance level of main effect term of genotype in full model. All statistical analyses were performed using Statistical Analysis System software (version 8.01, SAS Institute, Cary, NC, USA).

\section{Results}

The distribution of age, smoking history, and histological cell type of 171 lung cancer cases and 196 hospital controls are summarized in Table I. The mean age was $61.0 \pm 8.4$ in cases, and $62.1 \pm 12.2$ in controls $(\mathrm{P}=0.25)$. The proportion of eversmokers ( $\geq 400$ cigarettes/lifetime) was higher in cases $(91.7 \%)$ than in controls $(81.4 \%)(\mathrm{P}<0.001)$. When ever-smokers were divided into light and heavy smokers by 35 pack-years, the proportion of heavy smokers in cases $(66.2 \%)$ was higher than that in controls $(29.4 \%)(\mathrm{P}=0.001)$. Also, the mean packyear in ever-smokers was higher in cases $(40.6 \pm 16.1)$ than in controls $(26.0 \pm 19.4)$. The most common cell type was squamous cell carcinoma (43.3\%).

The distribution of CYP2E1 RsaI in the control group did not divert from Hardy-Weinberg equilibrium $(\mathrm{P}=0.26)$. The frequency of CYP2E1 c2 allele in Korean (30\%) in this study was higher than that of Caucasian (4.8\%) (24) and Japanese $(19.1 \%)(8)$, and lower than that of Chinese (66.4\%) (7). $C Y P 2 E 1$ genotype was not associated with the lung cancer risk (Table II).

The frequency of the GSTM1 null genotype in Korean was similar to that of Caucasian $(52.6 \%$ vs. $53.1 \%)$, whereas the frequency of both GSTT1 genotypes was higher than that of Caucasian (54.6\% vs. 19.7\%) (24). GSTMI and T1 null genotypes were not associated with overall lung cancer $(\mathrm{OR}=1.4,95 \% \mathrm{CI}=0.85-2.14$ and $\mathrm{OR}=0.7,95 \% \mathrm{CI}=0.45$ 1.12 , respectively). However, when the lung cancer cases were stratified by the histological cell types, the risk of squamous cell lung cancer was significantly associated with the GSTM1 null genotype $(\mathrm{OR}=1.9,95 \% \mathrm{CI}=1.04-3.60)$ (Table II). Also, the interactive effect between the GSTM1 null genotype and smoking was observed in squamous cell lung cancer development $(\mathrm{P}$ for interaction $=0.04)($ Fig. 1$)$. 


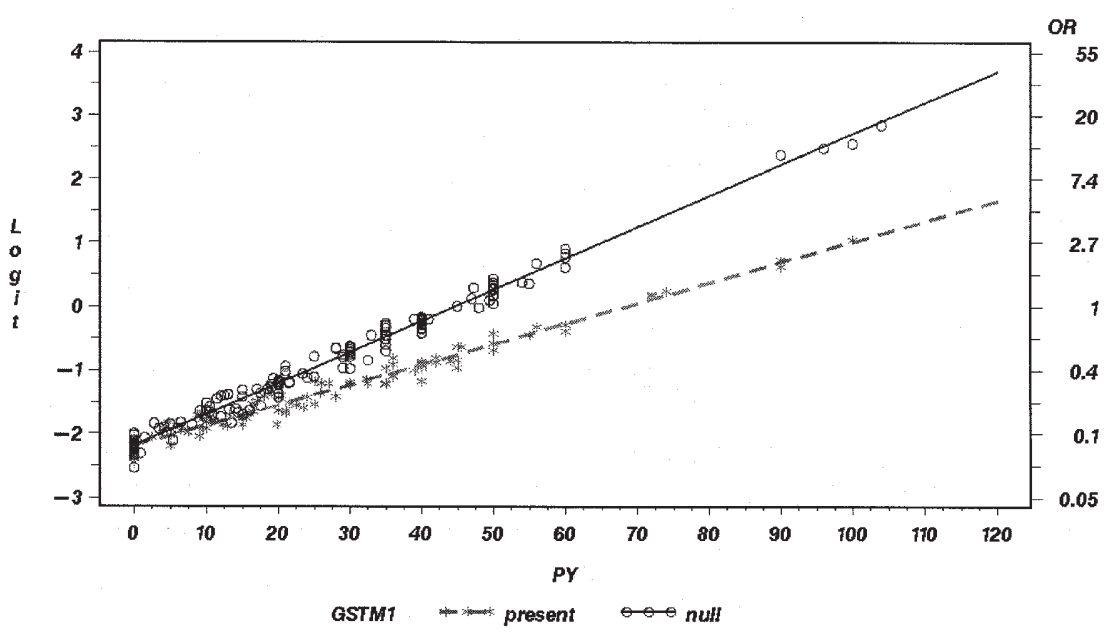

Figure 1. The interactive effect between the GSTM1 null genotype and smoking in squamous cell lung cancer was observed. It was evaluated by the difference of slopes of two fitted lines by genotypes using the following model with the assumption of common intercept; Logit (lung cancer) $=\beta_{0}+\beta_{1}$ age $+\beta_{2}$ pack-year + $\beta_{3}$ GSTM1*pack-year) $\left(\mathrm{H}_{0}: \beta_{3}=0 ; \mathrm{P}=0.04\right)$. This assumption, i.e. genetic effect does not exist if there is no exposure to smoking, was evaluated by the significance level of the main effect term of genotype in the full model $(\mathrm{P}=0.44)$.

\section{Discussion}

Our results suggest that the GSTM1 null genotype is associated with squamous cell lung cancer and there is an interactive effect between the GSTM1 genotype and smoking in squamous cell lung cancer development in Korean males.

Although stratified analyses by histological cell type in some previous studies did not show the association between GSTM1 null genotype and the risk of squamous cell lung cancer (SCC) $(25,26)$, the increased risk of SCC in relation with the GSTM1 null genotype in this study is consistent with the results of previous studies, including one meta-analysis $(6,12,27-29)$. Le Marchand et al (6) hypothesized that genetic susceptibility to PAHs (CYPIAl and GSTM1) predominantly causes SCC. In the study conducted by Le Marchand et al (6), CYP1Al MspI variant allele was associated with a 3.1-fold risk of SCC when combined with a GSTMI deletion. The decreasing trend of SCC associated with filter-tipped cigarettes in developed countries indirectly supports this hypothesis (30). The same trend was observed in Korea (31).

BPDE is known to induce $\mathrm{G}: \mathrm{C}$ to T:A transversion mutations in the hotspot codons of the p53 tumor suppressor gene (32), which is found more frequently in SCC than in $\mathrm{AD}$ (33). The BPDE-DNA adduct level is elevated in lung parenchyma of smokers with the GSTMI null genotype (34). Thus, it is speculated that our finding of the association between the GSTM1 null genotype and the risk of SCC is related with $\mathrm{PAH}$ exposure derived from smoking because PAHs are primarily metabolized by GSTM1.

We evaluated the interactive effect of genotypes with pack-year on lung cancer development under the assumption that, if there is no environmental exposure, there is no difference in the risk of lung cancer between genotypes $(22,23)$. We found that the association between cigarette smoking and squamous cell lung cancer was stronger among those with GSTM1 null genotypes. Although a number of previous studies examined the effect of interactions between the GST polymorphisms and smoking on the risk of lung cancer $(13,27,29,35-37)$, only a few studies found the interactive effects $(27,35)$.

Fig. 1 shows that, as the level of exposure to cigarette smoking increases, the effect of the GSTM1 genotype on the association between smoking and lung cancer risk also increases. This kind of effect was named as the high exposuregene (HEG) effect (23) and is consistent with previous studies $(27,35)$. Therefore, it is speculated that cigarette smoke exposure did not cause enzyme saturation of GSTM1 in this study population.

There were several limitations, including not collecting various potential confounding factors, and small sample size. Although potential confounding factors, such as occupational exposure and dietary factors, were not collected in this study, they seem to be relatively weakly associated with lung cancer compared with cigarette smoking, and the association with genotypes determined in this study seems unlikely. However, more subjects need to be recruited to evaluate the association of genotypes with the risk of lung cancer by specific cell type.

In summary, the results of our study suggest that genetic polymorphism of GSTM1 and its interaction with smoking play a role in squamous cell lung cancer development in Korean males. To investigate further the complex mode of interaction between genetic factors and environmental exposure, study including the comprehensive coverage of genes and collection of information on potential confounding factors is needed in the future.

\section{Acknowledgements}

This study was supported by the General Research Fund, Seoul National University (1998).

\section{References}

1. Parkin DM, Bray F, Ferly J and Pisani P: Estimating the world cancer burden: Globocan 2000. Int J Cancer 94: 153-156, 2001. 
2. Korean National Statistical Office: The census of death statistics, 2001

3. Hecht SS: Cigarette smoking and lung cancer: chemical mechanisms and approaches to prevention. Lancet Oncol 3: 461-469, 2002.

4. Kushida H, Fujita K, Suzuki A, Yamada M, Endo T, Nohmi T and Kamataki T: Metabolic activation of $\mathrm{N}$-alkylnitrosamines in genetically engineered Salmonella typhimurium expressing CYP2E1 or CYP2A6 together with human NADPH-cytochrome P450 reductase. Carcinogenesis 21: 1227-1232, 2000.

5. Persson I, Johansson I, Bergling H, Dahl M, Seidegard J, Rylander R, Rannung A, Hogberg J and Sundberg MI: Genetic polymorphism of cytochrome P4502E1 in a Swedish population: relationship to incidence of lung cancer. FEBS Lett 319: 207-211, 1993.

6. Le Marchand L, Sivaraman L, Pierce L, Seifried A, Lum A, Wilkens LR and Lau AF: Associations of CYP1A1, GSTM1, and $C Y P 2 E 1$ polymorphisms with lung cancer suggest cell type specificities to tobacco carcinogens. Cancer Res 58: 4858-4863, 1998.

7. Wang SL, Lee H, Chen KW, Tsai KJ, Chen CY and Lin P: Cytochrome P45021 genetic polymorphisms and lung cancer in a Taiwanese population. Lung Cancer 26: 27-34, 1999.

8. Watanabe J, Yang JP, Eguchi H, Hayashi S, Imai K, Nakachi K and Kawajiri K: An RsaI polymorphism in the CYP2E1 gene does not affect lung cancer risk in a Japanese population. Jpn J Cancer Res 86: 245-248, 1995.

9. London SJ, Daly AK, Cooper J, Carpenter CL, Navidi WC, Ding L and Idle JR: Lung cancer risk in relation to the CYP2E1 RsaI genetic polymorphism among African-Americans and Caucasians in Los Angeles County. Pharmacogenetics 6: 151-158, 1996.

10. Strange RC, Spiteri MA, Ramachandran S and Fryer AA: Glutathione-S-transferase family of enzymes. Mutat Res 482: 21-26, 2001.

11. Brockmoller J, Cascorbi I, Kerb R, Sachse C and Roots I: Polymorphisms in xenobiotic conjugation and disease predisposition. Toxicol Lett 102-103: 173-183, 1998

12. Cuzick J: Interaction, subgroup analysis and sample size. In: Metabolic Polymorphisms and Susceptibility to Cancer. Vineis P, Malats N, Lang M, d'Errico A, Capraso N, Cuzick J and Boffeta P (eds). IARC Scientific Publication, Lyon, pp109-121, 1999.

13. Benhamou S, Lee WJ, Alexandrie AK, Boffetta P, Bouchardy C, Butkiewicz D, Brockmoller J, Clapper ML, Daly A, Dolzan V, Ford J, Gaspari L, Haugen A, Hirvonen A, HusgafvelPursiainen K, Ingelman-Sundberg M, Kalina I, Kihara M, Kremers P, Le Marchand L, London SJ, Nazar-Stewart V, Onon-Kihara M, Rannug A, Romkes M, Ryberg D, Seidegard J, Shields P, Strange RC, Stucker I, To-Figueras J, Brennan P and Taioli E: Meta- and pooled analyses of the effects of glutathione S-transferase M1 polymorphisms and smoking on lung cancer risk. Carcinogenesis 23: 1343-1350, 2002.

14. Lu W, Xing D, Qi J, Tan W, Miao X and Lin D: Genetic polymorphism in myeloperoxidase but not GSTM1 is associated with risk of lung squamous cell carcinoma in a Chinese population. Int J Cancer 102: 275-279, 2002.

15. Persson I, Johansson I, Lou YC, Yue QY, Duan LS, Bertilsson L and Ingelman-Sundberg M: Genetic polymorphism of xenobiotic metabolizing enzymes among Chinese lung cancer patients. Int J Cancer 81: 325-329, 1999.

16. Wang J, Deng Y, Cheng J, Ding J and Tokudome S: GST genetic polymorphisms and lung adenocarcinoma susceptibility in a Chinese population. Cancer Lett 201: 185-193, 2003.

17. Chan-Yeung M, Tan-Un KC, Ip MS, Tsang KW, Ho SP, Ho JC, Chan $\mathrm{H}$ and Lam WK: Lung cancer susceptibility and polymorphisms of glutathione-S-transferase genes in Hong Kong. Lung Cancer 45: 155-160, 2004.

18. Risch A, Wikman H, Thiel S, Schmezer P, Edler L, Drings P, Dienemann H, Kayser K, Schulz V, Spiegelhalder B and Bartsch H: Glutathione-S-transferase M1, M3, T1 and P1 polymorphisms and susceptibility to non-small cell lung cancer subtypes and hamartomas. Pharmacogenetics 11: 757-764, 2001.

19. Sunaga N, Kohno T, Yanagitani N, Sugimura H, Kunitoh H, Tamura T, Takei Y, Tsuchiya S, Saito R and Yokota J: Contribution of the NQO1 and GSTT1 polymorphisms to lung adenocarcinoma susceptibility. Cancer Epidemiol Biomarkers Prev 11: 730-738, 2002.
20. Nazar-Stewart V, Vaughan TL, Stapleton P, Van Loo J, NicolBlades B and Eaton DL: A population-based study of glutathione S-transferase M1, T1 and P1 genotypes and risk for lung cancer. Lung Cancer 40: 247-258, 2003.

21. Lee SJ, Cho SH, Park SK, Kim SW, Park MS, Choi HY, Choi JY, Lee SY, Im HJ, Kim JY, Yoon KJ, Choi H, Shin SG, Park TW, Rothman N, Hirvonen A and Kang D: Combined effect of glutathione S-transferase M1 and T1 genotypes on bladder cancer risk. Cancer Lett 177: 173-179, 2002.

22. Taylor JA, Umbach DM, Stephens E, Castranio T, Paulson D, Robertson C, Mohler JL and Bell DA: The role of N-acetylation polymorphism in smoking-associated bladder cancer: evidence of a gene-gene-exposure three-way interaction. Cancer Res 58: 3603-3610, 1998

23. Taioli E, Zocchetti C and Garte S: Models of interaction between metabolic genes and environmental exposure in cancer susceptibility. Environ Health Perspect 106: 67-70, 1998.

24. Garte S, Gaspari L, Alexandrie AK, Ambrosone C, Autrup H, Autrup JL, Baranova H, Bathum L, Benhamou S, Boffetta P, Bouchardy C, Breskvar K, Brockmoller J, Cascorbi I, Clapper ML, Coutelle C, Daly A, Dell'Omo M, Dolzan V, Dresler CM, Fryer A, Haugen A, Hein DW, Hildesheim A, Hirvonen A, Hsieh LL, Ingelman-Sundberg M, Kalina I, Kang D, Kihara M, Kiyohara C, Kremers P, Lazarus P, Le Marchand L, Lechner MC, van Lieshout EM, London S, Manni JJ, Maugard CM, Morita S, Nazar-Stewart V, Noda K, Oda Y, Parl FF, Pastorelli R, Persson I, Peters WH, Rannug A, Rebbeck T, Risch A, Roelandt L, Romkes M, Ryberg D, Salagovic J, Schoket B, Seidegard J, Shields PG, Sim E, Sinnet D, Strange RC, Stucker I, Sugimura H, To-Figueras J, Vineis P, Yu MC and Taioli E: Metabolic gene polymorphism frequencies in control populations. Cancer Epidemiol Biomarkers Prev 10: 1239-1248, 2001.

25. Lewis SJ, Cherry NM, Niven RM, Barber PV and Povey AC: GSTM1, GSTT1 and GSTP1 polymorphisms and lung cancer risk. Cancer Lett 180: 165-171, 2002.

26. Alexandrie AK, Nyberg F, Warholm $M$ and Rannug A: Influence of CYP1A1, GSTM1, GSTT1, and NQO1 genotypes and cumulative smoking dose on lung cancer risk in a Swedish Population. Cancer Epidemiol Biomarkers Prev 13: 908-914, 2004.

27. Hirvonen A, Husgafvel-Pursiainen K, Anttila S and Vainio H: The GSTM1 null genotype as a potential risk modifier for squamous cell carcinoma of the lung. Carcinogenesis 14: 1479-1481,1993.

28. Saarikoski ST, Voho A, Reinikainen M, Anttila S, Karjalainen A, Malaveille C, Vainio H, Husgafvel-Pursiainen K and Hirvonen A: Combined effect of polymorphic GST genes on individual susceptibility to lung cancer. Int J Cancer 77: 516-521, 1998.

29. Pinarbasi H, Silig Y, Cetinkaya O, Seyfikli Z and Pinarbasi E: Strong association between the GSTM1-null genotype and lung cancer in a Turkish population. Cancer Genet Cytogenet 146: 125-129, 2003.

30. Wyner EL and Hoffman D: Smoking and lung cancer: scientific challenges and opportunities. Cancer Res 54: 5284-5295, 1994

31. Kim JS, Park JY, Chae SC, Shin MC, Bae MS, Son JW, Kim KY, Kang TK, Park KS, Kim CH, Kam S and Jung TH: Changing trends of clinical aspects in lung cancer from 1988 to 1996. J Korean Cancer Assoc 31: 112-119, 1999.

32. Denissenko MF, Pao A, Tang M and Pfeifer GP: Preferential formation of benzo[a]pyrene adducts at lung cancer mutational hotspots in P53. Science 274: 430-432, 1996.

33. Greenblatt MS, Bennett WP, Hollstein M and Harris CC: Mutations in the $p 53$ tumor suppressor gene: clues to cancer etiology and molecular pathogenesis. Cancer Res 54: 4855-4878, 1994.

34. Alexandrov K, Cascorbi I, Rojas M, Bouvier G, Krief E and Bartsch H: CYP1A1 and GSTM1 genotypes affect benzo[a]pyrene DNA adducts in smokers' lung: comparison with aromatic/ hydrophobic adduct formation. Carcinogenesis 23: 1969-1977, 2002.

35. Kihara M, Kihara M and Noda K: Lung cancer risk of GSTM1 null genotype is dependent on the extent of tobacco smoke exposure. Carcinogenesis 15: 415-418, 1994.

36. Hou SM, Falt S and Nyberg F: Glutathione S-transferase T1null genotype interacts synergistically with heavy smoking on lung cancer risk. Environ Mol Mutagen 38: 83-86, 2001.

37. Schneider J, Bernges U, Philipp M and Woitowitz HJ: GSTM1, GSTT1, and GSTP1 polymorphism and lung cancer risk in relation to tobacco smoking. Cancer Lett 208: 65-74, 2004. 